\title{
Alex Fryszman
}

\section{Retorikkens løgnagtige tale og det fremmede blik i spejlet}

I

Selv om Bachtins navn forlængst er blevet fælles gods i de humanistiske videnskaber på internationalt plan, forbliver flere af hans tekster ukendte for den danske læser. De følgende artikler må snarere læses som eksperimenterende og næsten stenografiske optegnelser af tankens bevægelser end som fuldbyrdede formuleringer af Bachtins teoretiske holdninger. »Retorikkens løgnagtighed « præsenterer læseren for Bachtins indre monolog om retorik, vold og autoritet. »Mennesket i spejlet« er et ultrakort, provokerende udkast til en fænomonologisk skitse om det spejlvendte blik.

Kronologisk set kommer artiklerne i kølvandet på Bachtins banebrydende »Epos og roman« (1941), men adskiller sig fra denne både ved deres stærkt aforistiske præg og tydelige paralleller til hans antropologiske, eksistentielle og fænomenologiske motiver fra 1920'ernes produktion. ${ }^{1}$

På den anden side ligger de i forlængelse af Bachtins analyser af romanens sproglige pluralisme og dens særpræg som dialogisk kunstform. Allerede i »Ordet i romanen« (1935) opfordrer Bachtin til »radikal filosofisk omvurdering af det poetiske ords betydning. $\ll^{2}$ Denne omvurdering formuleres som en tvefoldig polemik. I relation til formalisternes poetik markerer Bachtin sin vending mod en hermeneutisk refleksion. I relation til den frembrydende ideologiske ensretning, insisterer han på den æstetiske kunstforms frihed for didaktiske interesser. Værket rummer mangfoldige henvisninger til retorikken, samtidig med at det sondrer mellem den retoriske og litterært-prosaiske dialogicitet. ${ }^{3}$ Romanens tilblivelse hævdes at indgå i »uophørlig vekselvirkning med de levende retoriske genrer (filosofiske, etiske, publicistiske o.a.), der rivaliserer med romanens assimilering af de klassiske kunstgenrer (episke, dramatiske og lyriske). $\ll^{4}$

Bachtin anerkender retorikkens genremæssige betydning, men konkluderer, at romanens diskurs bevarer sit særpræg som en kunstform, der aldrig lader sig reducere til hverken det retoriske eller didaktiske ord. Bachtins kritik af forma- 
lismen retter sig mod dens snæversynede relativering af romanens $d y b e$ betydningsunivers, der reduceres til et decorum, kulissen for de poetiske kunstgreb, troper og figurer. ${ }^{5}$ Alligevel synes det påfalende, at Bachtins tidligere tekster kan diskutere retorikken uden de stærkt negative og fordømmende undertoner, der indledes med det nærværende essay og kulminerer i 1970'ernes optegnelser.

»Den retoriske strid stræber mod en sejr over modstanderen og ikke mod en tilnærmelse til sandheden. $\ll^{6}$ Med denne optegnelse fra 1971 slutter Bachtins vidtstrakte refleksioner omkring den retoriske afgørelse versus den dialogiske forståelse. I stedet for formalismens aristoteliske forudsætninger, fængsles hans interesse af retorikkens ophav i den sofistiske tradition. Den knyttes som regel til de spørgsmål som rejses i Dostojevskijs romanunivers. Over for litteraturens dialogiske sandhedss øgen, der tilstræber forståelsens åbenhed, stiller han den retoriske stræben mod stridens afsluttende udgang i en sejr over modparten. Dostojevskijs parodiske fremstilling af retssalens rum er ifølge Bachtin polemisk vendt mod den juridiske retoriks relativering af sandheden, hvor striden om de pragmatiske interesser camoufleres under den objektive upartiskhed. ${ }^{7}$ I en anden symptomatisk optegnelse fra 1970'erne insisterer Bachtin explicit på paralleller mellem den juridiske og retoriske afgørelse: »I retorikken findes der kun ubetinget retfærdige og ubetinget skyldige; retorikken stræber mod en total sejr og tilintetgørelse af modstanderen. I dialogen vil en sejr over modstanderen betyde en tilintegørelse af ordets dialogiske liv « ${ }^{8}$

I de efterfølgende passager henviser Bachtin til Dostojevskijs emfatiske undsigelse af den $\gg$ upersonlige, upartiske og objektive sandhed, det vil sige en sandhed ud fra den tredjes synspunkt. Den tredjes domstol er en retorisk domstol. Bemærk Dostojevskijs syn på retten og jurydomstolen. ${ }^{9}$

Den tredie, upartisk dømmende instans, der skiller ret fra uret, kan ifølge Bachtin optræde under forskellige moderne forklædninger, fra den almene rationalitet til historiens dialektiske logik. Bachtin peger på romankunstens fremstilling af Dommeren, hvis dystre skikkelse med al prægnans kommer til syne som Storinkvisitoren fra Brødrene Karamazov. Storinkvisitorens figur tilbyder læseren af »Retorikkens løgnagtighed « en vigtig fortolkningsnøgle. Den skinner tydeligt igennem Bachtins refleksioner over »voldens remedier for tingsliggørelse af mennesket. « Mod essayets slutning kommer han explicit ind på den epokale inkvisitoriske blindhed over for den meningsmæssige idealitet og meningen i sig selv, der kaster et ejendommeligt lys tilbage over $L e$ genden om Storinkvisitoren.

De gensidige, dynamiske oppositioner mellem retorik, dialektik og dialogik danner en rød tråd, der løber gennem flere af Bachtins skrifter. Dialogen placererer sig midtvejs mellem den medierende dialektiske forsoning og den re- 
toriske strid. Over for den kumulative dialektiske sandhed fastholder dialogen perspektivernes mangfoldighed og den enkelte stemmes uerstattelige egetværd. Over for det retoriske begær efter »det sidste ord «, der overbeviser og besejrer modparten, appellerer den til forståelsens principielle uendelighed og uafgjorthed.

I Bachtins tidligere tekster er argumenterne mod misbrug af retorikken polemisk vendt mod formalismens landvindinger. Uden at bestride formalismens indsigter i romanens figurative univers, betoner Bachtin, at formalismen har lukket litteraturen inde i en retorisk glasklokke. Men allerede med de første tilsynekomster af tredivernes autoritative offentlighed synes denne tvetydige kritik af retorikken mere og mere knyttet til Bachtins tiltagende accentuering af vold, tvang og terror. Hvordan skal man vurdere betydningen af essayets lidenskabeligt »antiretoriske« retorik?

Det synes indlysende, at Bachtins tankeunivers snarere må placeres inden for, og ikke uden for den retoriske tradition. Den form for kritik, han udfolder, må derfor vurderes som en dialogisk kritik indefra. Bachtin betoner flere forskellige steder, at antikken endnu ikke kender til nogen uoverstigelig kløft mellem retorik og litteratur. Det vigtigste hermeneutiske forbillede for den antikke litteraturs fremstilling af retssalens retorik er for Bachtin de sokratiske dialoger "på tærskelen « mellem liv og død, der knytter sig til retssagen og dommen (især Apologien og Faidon). Mere sporadisk og indirekte kommer Bachtin ind på dialogen Gorgias, der explicit kritiserer de negative aspekter af sofisternes retorik. ${ }^{10}$ Domstolens litterære kronotoper (tidens/rummets anskuelsesformer) analyseres af Bachtin uden det påfaldende stærke lidenskabelige engagement, der præger essayet om retorikkens løgnagtighed. ${ }^{11}$ Gentagne gange kan Bachtin føre romanens forhistorie tilbage til dens sammenvævede trefoldige rødder i de sofistiske (retoriske), dialogiske (sokratiske) og dramatiske (komediens og tragediens) forbilleder. I hovedværket om Dostojevskijs poetik (1929) kan man overalt konstatere Bachtins fortrolige og forholdsvis fredsommelige forhold til den retoriske tradition. Han kan eksempelvis insistere på en modsætning mellem det autoritative ord og det indre, overbevisende ord, der altid søger en responsforståelse. ${ }^{12}$ Er Bachtins »overbevisende « og »handlende « ord ikke en retorik i ordets eminente betydning? Samtidig gør han systematisk rede for den retoriske teknik i den sokratiske jordmoderkunst. Det som interesserer Bachtin ved den sokratiske dialog er imidlertid ikke den retoriske argumentationsmåde (inventio argumentorum), men snarere kunsten at stimulere dialogens dynamik, føre modstandere sammen, sætte dem på prøve og skabe dialogiske »kriser.« Han foretrækker helt klart de dialoger, der ikke har en meningsmæssig afslutning, men munder ud i en aporetisk uafgjorthed. End- 
nu vigtigere for Bachtin er dialogens elenktiske fremdrift, der ytrer sig i en uophørlig bestræbelse på at undgå afgørelsen og begynde samtalen på ny. ${ }^{13}$

Anderledes med den nærværende tekst. Dens mest iøjnefaldende træk er en overraskende sammenknytning mellem retorik og vold. Denne kobling synes at rumme en underforstået pointe. Mit bud er, at teksten kritiserer magtsprogets offentlige, monologiske retorik og ikke den retoriske tradition. Den sidstnævnte bedømmes aldrig af Bachtin som »monologisk. « Han lader den snarere skyde sig ind imellem de autentisk dialogiske og monologiske diskursive former. For at yde Bachtin retfærdighed og følge hans tankegang er det vigtigt at drage en skillelinje mellem den officielle og uoficielle retorik.

»Retorikkens løgnagtighed « skal således læses på sine egne præmisser, der ikke lader sig løsrive fra tekstens kronotop: tilblivelsen af samtidens officielle, offentlige rum med dets ensrettede og formaliserede sprogbrug. Bachtins kritik vender sig derfor hverken mod de traditionelle eller de nyere retoriske genrer, men mod magtens autoritative sprog. Storinkvisitorens tilbagekomst bliver en uimodsigelig historisk kendsgerning i samtidens offentlige kommunikation. Især i den offentlige sfære bliver det retoriske ord forvandlet til en spændetrøje, som formaliserer den normative sprogbrug og udjævner alle individuelle og dialogiske elementer:

»Det oprindeligt gode, uselviske og kærlige menneske har endnu ikke talt, han realiserer sig selv i dagligsfæren, han berører ikke det organiserede ord, som er besmittet med løgn og vold, han bliver ikke en forfatter. Godhed og kærlighed, såfremt de findes hos forfatteren, forlener ordet med ironi, usikkerhed, undseelse (skamfuldhed over det alvorlige).«

I den monologiske kultur kommer den officielle sandhed til syne som terror og vold:

»Sandheden havde endnu aldrig været i familie med mennesket, kom ikke til det indefra, men udefra; den kom altid som besættende sejrherre. Den var en åbenbaring, men den var ikke åbenhjertig; den fortiede altid et eller andet, omgav sig med hemmelighed, og følgelig med vold.«

Dostojevskijs læser vil utvivlsomt genkende Storinkvisitorens dystre skygge fra Brфdrene Karamazov og romanforfatterens betoning af autoritet, vold og hemmelighed som magtens inkvisitoriske remedier. På den anden side er fremkomsten af den autoritative retoriks uindskrænkede magt en epokal kendsgerning, der kaster et korrigerende lys over essayets excentrisk unuancerede og tilsyneladende problematiske bedømmelse af retorikken. I magtspro- 
gets instrumentale og manipulerende misbrug af retorikken bliver ordets formålsrettede effekt det altafgørende. Derfor opvurderer Bachtin det poetiske, polysemiske, tøvende og formålsløse ord, som lever i privatsfæren og ikke styres af nogen formålsbestemt interesse. Ordet kan hos Bachtin undertiden optræde som et selvstændigt, autonomt subjekt med sit eget etiske og emotionelle liv. Det kan skamme sig over sig selv, lide og vride sig i smertens kramper eller kaste misundelige »sideblik « mod andre ord. I nærværende essay insisterer Bachtin derimod på ordets hjemløshed: »Ordet ved ikke hvem det tjener, det kommer fra mørket og kender ikke sine rødder.«

Som det fremgår af essayet, kan magtens retorik strække sig fra den renlivede politiske propagandas »jern og blod « til de mindre brutale, men ligeså anakronistiske filosofiske fordringer om en objektiv virkelighedserkendelse. I de mest forskellige fænomener ser Bachtin virkninger af de monologiserende kræfter, der appellerer til almen rationalitet og sandhed, videnskab og historiens dom. Disse instanser bliver absoluteret som den upartiske »tredje « adressat, men $\emptyset$ ver i realiteten terror mod den individuelle frihed og kulturens dialogiske dynamik.

Dermed kommer vi til at berøre Bachtins tilbagevendende tema: den individuelle frihed til at vælge en anden personlig identitet end den forudbestemte og foreskrevne af de ydre instanser. Denne frihed finder han hos Dostojevskijs helt, der færdes i tidens »brudflader og nedrivninger.« Dostojevskij åbner for muligheder for at bryde op fra Inkvisitorens fangehul, og hans roman rummer en bestandig påmindelse om, at mennesket ikke er fastlåst $\mathrm{i}$ en udefra påtvunget biografisk fortælling: »Et menneske dør og føder af sig selv et fuldstændig andet og nyt menneske uden kontinuerlig forbindelse med det første jeg.«

Det »terroristiske ord « søger derimod altid at definere de andre udefra. Det være sig »alle de andre« fra Dostojevskijs romaner, »den objektive erkendelse « $i$ en positivistisk præget filosofi eller samtidens litteraturvidenskab, der reducerer kunstværker til magtens remedier. Bachtin insisterer på, at »løgnen er den mest moderne og aktuelle form for det onde«, der trives ikke blot på meningens niveau, men også i »den kunstneriske form «. Hans slutbemærkninger om løgnens moderne forfinelse og »løgnens fænomenologi« synes atter at pege tilbage på Dostojevskijs univers. Storinkvistorens retorik, som Bachtin i det umiddelbart efterfølgende henviser til, er som bekendt autoritativ, men ingenlunde løgnagtig (den lader sig snarere beskrive i oksymoroniske termer som »sandhedens løgn «). I stedet for den ekskluderende, bivalente logik (tertium non datur) opererer Dostojevskij med en ambivalent dia-logik. ${ }^{14}$ Denne iagttagelse, som Bachtin noterer sig andre steder, synes til en vis grad at gælde nærværende essay. Den retoriske løgn er ikke sandhedens modsætning. Bachtins evaluering af talens sandhed lader sig trods alt ikke løsrive fra hans tilba- 
gevendende spørgsmål: hvem taler? Det dialogiske »hvem« og det retoriske »hvordan « går forud for de substantielle indholdsbestemmelser. Lad os derfor nøjes med at fastholde essayets sammenvævning af »sandhedens « monologiske, institutionaliserede terror og retorikkens normsættende vold.

\section{II}

Bachtin indleder sit polemiske essay med at pege på det retoriske ords instrumentale væsen. Dets angtsfremkaldende effekter stilles over for tragediens og latterens frigørende virkning, der forløser ordet og tilbagekalder angsten. Vi møder straks den for perioden karakteristiske erkendelse af angstens og frygtens betydning, der sættes i sammenhæng med latterens og alvorens dialogiske enhed. ${ }^{15}$ På den anden side forholder Bachtin sig afvisende over for den episke bevidstheds afsluttede betydningsunivers, der udtømmer fremtidens muligheder ved at placere værdicentret i den absolutte fortid. Allerede Pusjkins prosaiske flersproglighed i »romanen på vers « Jevgenij Onegin modsætter sig den episke ophøjelse af fortidens forbilleder til en etisk og æstetisk lov. Pusjkins dybt ironiske »roman« indvarsler muligheder for flere dialogiske perspektiver på samme fænomen og bebuder et brud med den stilrene form og homogene mening. Romanens seriokomiske fremdrift bryder fortidens fastlåsning og bevarer et meningsoverskud til at forholde sig til både nuet og fremtiden.

Det bliver imidlertid hos Bachtin først og fremmest Dostojevskijs roman, der åbner for de nye subjektfilosofiske og antropologiske perspektiver. Den nyere forskning har kunnet påvise de stærke impulser, som Bachtin har modtaget fra både Søren Kierkegaard, Martin Bubers dialogfilosofi og Helmuth Plessners fænomenologiske antropologi, hvorfra Bachtin overtager sine teser om menneskets konstitutive excentricitet og positionalitet. På denne baggrund kan man forstå essayets bratte tematiske overgange fra retorik til epos og fra Pusjkins tvetydighed til heltens revolte i Dostojevskijs roman. Dostojevskij konstituerer heltens porøse selvbevidsthed i ekscentriske krisepunkter og biografiske brudflader. Helten »falder ud « af den fremadskridende biografiske og historiske tid. Modsat $\mathrm{i}$ »eposets « historiefilosofiske perspektiv finder han ikke længere fodfæste $\mathrm{i}$ et bestemt meningsunivers og mister med Bachtins udtryk enhver »kontinuitet « $\mathrm{i}$ forhold til sig selv.

Heltens selvreflekterende bevidsthed bryder bestandig op med sig selv på en måde, der ikke længere rummes i de endimensionale og homogene narrative former. Den drages ind i en bevægelse, som kræver anderledes kompleksitet og mangfoldighed. Bachtin taler i essayet om »selvbevidsthedens evige proces mellem jeget og den anden«. Den karakteristiske metaforik synes 
at pege på en uendelig retssag, en procedure der modsat den juridiske retorik aldrig vil nå frem til domstolens afgørelse. Essayets forgrenede dialogisme udvider bestandig perspektivernes rigdom, således at Bachtins polemik mod den retoriske vold på samme tid kommer til at omfatte en række tilsyneladende højst forskellige fænomener som »den objektive erkendelse« og den russiske formalismes objektiviserende begrebsliggørelse af det autonome litterære felt.

»Voldens element findes både i erkendelsen og i den æstetiske form.« Den kommunikative vold finder Bachtin både i erkendelsens autonome, lukkede begreber og i de fastlåste, afsluttede æstetiske former. I begge tilfælde krænkes den andens frihed. Kun på baggrund af Bachtins filosofiske skrifter fra 1920'erne kan man begribe essayets provokerende sammenligning mellem den monologiske virkelighedserkendelse og kannibalisme (antropofagi) ${ }^{16}$ De foregriber essayets kritik af volden i den umiddelbare tilegnelse (»fortæring «) af et fremmed betydningsunivers, der enten undertvinges eller formes i mit billede. Den dialogiske dynamik, der vil fastholde den andens irreducible »meningsoverskud « må ifølge Bachtin gennemføre en tredobbelt bevægelse. Den måde, hvorpå den anden kommer til syne inden for min horisont (»den anden for mig «), må suppleres med mit forsøg på at sætte mig i den andens sted og se mig selv fra det fremmede perspektiv (»jeg for den anden«). Endelig fordrer Bachtin en anerkendelse af subjektets forhold til sig selv (»jeg for mig selv«) som »det operative nervecenter « for handlingen. ${ }^{17}$ Subjektiviteten spalter sig sig således i tre væsensforskellige perspektiver, hvis samspil skal fastholdes. Ingen af dem kan blive autonome eller selvtilstrækkelige uden at det medfører tab af frihed.

\section{III}

Den bevægelige positionalitet kommer til at danne et udgangspunkt for Bachtins fænomenologiske antropologi, som mere udførligt udfoldes i andre skrifter. I Retorikkens løgnagtighed og Mennesket ved spejlet nøjes han med at understrege menneskets »udenforståenhed « i relation til sig selv. Den menneskelige eksistens udfolder sig altid på tærskelen eller i skæringspunkter mellem de forskellige perpektiver. Blandt de forskellige filosofiske intertekster, der brydes i det bachtinske essay, er det værd at notere sig markante impulser fra 1920'ernes fænomenologiske opvurdering af rummets betydning for perceptionen og de emotionelle livsytringer som sympati, ømhed eller indlevelse. Den litterære sandhedssøgen defineres i »Retorikkens løgnagtighed « som »søgen efter et nyt rum for mødet mellem jeget og en anden, efter et nyt rum for 
at bygge menneskebilledet op. « De interpersonale relationer giver sig ifølge Bachtin til kende selv i de tilsyneladende selvspejlende emotioner, som i det skjulte forudsætter en andens eksistens og bliver derved også et møde med en anden eksistens: »kærlighed til sig selv, selvmedlidenhed, selvnydelse er kompliceret i deres sammensætning og specificitet. Alle de åndelige elementer af kærlighed til sig selv og selvvurdering er en usurpation af en andens sted, en andens synspunkt. «Den irreducible tilstedeværelse af en anden redder den filosofiske erkendelse, eftersom den rene tænkning aldrig formår at begrunde sig selv. Hos Bachtin fremtræder »den anden« ikke som en trussel mod »den første«, men varsler håb som en chance for at blive reelt perciperet, accepteret, bekræftet »udefra.« Bachtin er således trofast mod ordets russiske semantik, hvor »den anden $«\left(\right.$ drugoj) udledes af ordet drug (en ven). ${ }^{18}$

Essayets slutning, der opfordrer til en ny filosofisk forundring over for de mest elementære fænomener, klinger godt sammen med den efterfølgende, ultrakorte optegnelse, »Mennesket i spejlet.« Situationen »ved spejlet« er en af de tilbagevendende metaforer i de bachtinske tekster. Som Holquist \& Clark konkluderer i deres monografi, handler metaforen aldrig om den passive spejling à la Lacans »spejlstadium «: Bachtin refererer til selvbevidsthedens aktive tilblivelse, hvor de andres optikker brydes i spejlets glasflade. ${ }^{19}$ Optegnelsen knytter tilbage til de provokerende slutkonklusioner fra »Retorikkens løgnagtighed «: »Jeg sætter mig altid mellem to stole. Jeg bygger mit eget billede op (bliver selvbevidst) på samme tid både ud fra mig selv og ud fra en andens synspunkt.«

Bachtins urokkelige optimisme klinger umiskendeligt i disse ord fra det dystre år 1943. Den udspringer fra selve kilden til hans filosofiske tanke, der bestandig negerer enhver mulighed for subjektets selvtilstrækkelige ensomhed. Allerede kroppens erfaringsfelt indebærer en henvisning til mere end mit eget jeg. De mest fundamentale fænomener, som sympati, kærlighed, medlidenhed eller ømhed kan ifølge Bachtin pege på selvbevidsthedens udspring $\mathrm{i}$ de interpersonale relationer. »Mennesket i spejlet « viser, at en andens nærvær er givet på forhånd og ikke kan vælges fra. Det gælder ikke blot rummets, men også tidens dimension. Såvel legemligheden som selvrefleksionen henviser til en anden bevidsthed end min egen. På samme måde forholder det sig med de konstitutive træk ved min eksistens (min fødsel og død er utilgængelige for min bevidsthed). De fordrer den andens blik, på samme måde som mine ord vil brydes i de andres ord, der atter griber ind $\mathrm{i} » \min$ egen tale. « De fremmede $\varnothing j n e$ vil altid møde mit eget blik i spejlet. 


\section{Noter}

1. Blandt de brogede filosofiske kilder Bachtin selv henviser til, er den klassiske tyske filosofi, neokantianismen (Marburg-skolen), livsfilosofien (Nietzsche, Dilthey, Simmel, Bergson), fænomenologien (Husserl, Scheler, Heidegger), fænomenologisk antropologi (Plessner og Lipps). På den anden side modtager han vigtige inspirationer fra Søren Kierkegaard, dialogfilosofien (Martin Buber) og eksistensfilosofien (Karl Jaspers).

2. M. M. Bachtin: »Slovo v romane«; Voprosy Literatury i Éstetiki, Moskva 1975; p. 80 .

3. »Ordet i romanen« placerer retorikken mellem den dialogiske og den monologiske tale. Han anerkender en særegen retorisk dialogicitet, som er forskellig fra den »prosaiske«, ibid. p.166.

4. Ibid., p. 82.

5. Ibid., p.165-166.

6. Bachtins optegnelser fra 1970-1971 er oversat fra Estetika Slovesnogo tvortjestva, redaktion S. G. Botjarov. Moskva 1979, p. 357.

7. Ibid., p. $355 \mathrm{f}$.

8. Ibid.

9. Ibid.

10. Bachtins kendskab til Kierkegaards afhandling »Om Begrebet Ironi« forekommer mig evident. Jvfr. Alex Fryszman: »Kierkegaard and Dostoyevsky seen Through Bakhtin's Prism«, Kierkegaardiana 18, 1996; p. 100-126. Bakhtins referencer til de ældste romantikere (Fr. Schlegel, Jean Paul, Novalis) og til den romantiske ironi viser påfaldende overensstemmelse med Kierkegaard. Det samme gælder inpulser fra Ludvig Tieck og hans »bagvendte verden« (Die verkehrte Welt, 1838). Mere om Bakhtins forståelse af ironiprincippet, se Alex Fryszman: »Teoria kommunikatsii S. Kirkegora i dialog Bakhtina«/ »Bakhtin i perspektivy gumanitarnogo mysjlenija«, Vitebsk 1994, p. 31-38.

11. Bachtin kan eksempelvis definere »kronotop« som følger: »I Den transcendentale Astetik (et af de vigtigste afsnit i »Kritikken af den rene fornuft «) bestemmer Kant tidens og rummets anskuelsesformer som nødvendige for enhver erkendelse, samtidig med at han lader erkendelsen tage udgangspunkt i de mest elementære erfaringer ... Vi overtager for nærværende den kantianske vurdering af anskuelsensformens betydning for erkendelsens proces. Modsat Kant vil vi alligevel ikke opfatte dem som »transcendentale «, men som virkelighedens egne og yderst konkrete former. Vi skal således klargøre disse formers betydning for kunstens konkrete erkendelse (den kunstneriske optik), sådan som den udfolder sig under romangenrens betingelser. « Oversat efter Bachtins artikel »Formy Vremeni i Chronotopa v Romane« (1937-1938), M. M. Bachtin: Voprosy Literatury i Éstetiki, p. 235; Moskva 1975.

12. Læs mere herom i Bakhtin, M.M.: »The Dialogic Imagination; Four Essays by M. M. Bakhtin«, p. 346. Michael Holquist (ed.); trans. by Caryl Emerson and Michael Holquist. Austin, Texas, 1981.

13. »Elenktik « (af gr. elenchos: gendrivelse, eller prøvelse) betegner en strategi i en sokratisk dialog, der sætter modstanderen på prøve og fører til samtalens aporetiske udgang. Apori-begrebet anvendes ikke direkte af Bachtin, men synes at få betydning for hans læsning af Dostojevskij. At Dostojevskij aldrig fælder »det sidste 
ord « er således et bestandig tilbagevendende motiv i Bachtins værk om Dostojevskijs poetik.

14. Se eksempelvis tredie kapitel af Problemer i Dostojevskijs poetik. I Caryl Emersons oversættelse begynder passagen som følger: »In the monologic world, tertium non datur: a thought is either affirmed or repudiated; otherwise it simply ceases to be a fully valid thought. « Mikhail Bakhtin: Problems of Dostoevsky's Poetics, $\mathrm{p}$. 80. Edited and Translated by Caryl Emerson, Minneapolis 1984.

15. Denne indledning korresponderer påfaldende med et næsten samtidigt foredrag, Bachtin afholdt 24. marts 1941, hvor en af de mest karakteristiske formuleringer lyder: »Tragediens dristige alvor fordrer mandsmod, der forbliver inden for individualitetens lukkede rammer. Anderledes med latteren, der veksler mellem glæden og skændslen. Men såvel tragedien som latteren er fælles om deres fjendtlighed mod moralsk optimiske anskuelser; de varsler afsky for både alle snæversynede harmoniske kontruktioner (man kan hverken »harmonisere« det forhåndenværende eller det kommende, som endnu ikke er til) og samtlige ynkelige idealistiske sublimeringer. Såvel tragedien som latteren kan se tilværelsen i øjnene uden frygt og illusioner; de er nøgterne og krævende.« Min oversættelse af citatet fra arbejdspapirer til foredraget »Romanen som litterær genre«, M. M. Bachtin: Samlede Varker, Moskva 1995, p. 463.

16. Det efterfølgende refererer primært til Bachtins afhandling »Mod en handlingsfilosofi «, som formentligt er skrevet i løbet af perioden 1920-1924. Jeg vælger her at følge den første russiske udgivelse: M.M. Bachtin: »K Filosofii Postupka«, Moskva, 1986, p. 80-138. Parallelle motiver kommer imidlertid til udtryk i flere forskellige samtidige Bachtin-skrifter.

17. M. M. Bachtin: »K Filosofii Postupka«, p. 127. I samme værk finder man en betoning af kærlighedens erkendelsesmæssige betydning (ibid. p. 130 f.), der viser slående paralleller med »Retorikkens løgnagtighed «.

18. Om begrebets modifikationer i den tradition som Bachtin synes beslægtet med, læs M. Theunissen: »The Other: Studies in the Social Ontology of Husserl, Heidegger, Sartre, and Buber«; trans. Ch. Macann, Cambridge 1984. Hertil kunne man tilføje at Bachtins »anden « viser stærke paralleller med Emmanuel Levinas' tænkning. I lighed med Levinas fastholder Bachtin, at den etiske handlen går forud for alle teoridannelser.

19. »As opposed to Lacan, Bakhtin cenceives the mirror stage as coterminous with consciousness; it is endless as long as we are in the process of creating ourselves, because the mirror we use to see ourselves is not a passively reflecting looking glass but rather the actively refracting optic of other persons «. Citeret fra Katerina Clark/Michael Holquist: Mikhail Bakhtin, p. 79, Cambridge, Mass., 1984. 